\title{
Ill-prepared Indonesian Government for Dealing with Covid-19 Pandemic and its Effect on the People
}

\author{
Kenan Wisaksena Hudawan \\ Faculty of Sociology and Politic, Sociology Major, \\ Universitas Islam Negeri Walisongo, Semarang - Indonesia
}

\begin{abstract}
The pandemic that occurred in 2019 is a global-scaled problem. The Covid-19 pandemic caused by Corona Virus has a significant impact on various aspects of life which has progressively changed human's life condition. Covid19 pandemic had impacted every nations around the world, including Indonesia. Ill-prepared government at anticipating Covid-19 pandemic, which is a critical matter, worsen the pandemic effect. It is also created a lot of problematic issues. One of them is cyber threat. The freedom and convenience of social media caused provocative, conspiracies, fake, and misleading news easier to be spreaded and circle around society which potentially harmful. This conditions get worse after Covid-19 pandemic occurs. Misleading news about Covid-19 has the potential to risk people's life severely. This cyber threat can lead to disbelief in Covid-19 pandemic itself, thus can worsen the effect. Another effect caused by ill-prepared government for Covid-19 pandemic is ill-prepared regulations that heavily impacted people's life. All of these issues resulted in disbelief of both pandemic and the government itself which highly threaten people's life, peace, and possibly national integrity. This article is writen based on research analysis with qualitative method with the purpose of understanding both government and its people dealing with Covid-19 pandemic and its threatening effects on society by tries to examine: 1 . How effective regulations following pandemic; 2. What is the effect on society; 3 . What kind of move government do to help its people; 4. How Indonesian people's understanding about Covid-19 pandemic; 5. What actions the goverement do to solve problems following the pandemic. Current situation shows that the government regulations in order to suppress Covid-19 virus worked, but ill-prepared makes it not effective since the regulations are very strict, contradictory, even created problems. For instance, small businesses are heavily affected, government grown too strict, and corruptions on government material grant. In order to oppress Covid-19 spreading, the government also took actions on misleading news spreader and maker.
\end{abstract}

Keywords: Pandemic of Covid-19; Government; Policy; Society; People's Condition 


\section{Introduction}

The pandemic that occurred in 2019 is a problem that occurs on a global. In other words, the Covid-19 pandemic caused by Corona Virus had a significant impact on various aspects of life which progressively and forcefully changed people's life. Social, behavioral, technological and educational developments, including industrialization, have also been affected by the pandemic. Government of the Republic of Indonesia officially announced the first case of Covid-19 on March 2, 2020 when two Jakarta civilians were tested positive, which later spread across all districts and cities. From this point, marked the start of the Covid-19 Pandemic in Indonesia. By January 30, 2021 record indicated that 14.518 reported case of Covid-19 which is the highest recorded case that happened in one day. By August 2021, total case of Covid-19 reported reached more than 4 millions case with around 50 thousand casualties related to the pandemic. The Covid-19 Pandemic has a serious impact on various aspects of Indonesian people's live, one of which threaten people's life and makes normal daily activities such as office works, field works, academic activities, and commerce related activities disrupted. As the result of this condition, people's economy and welfare conditions declined as the rate of unemployment and work dismissal increased.

Government of the Republic of Indonesia applying PPKM (Pemberlakuan Pembatasan Kegiatan Masyarakat) or Mass Social Activity Restriction regulation to restrict people's activity involving outdoor, mass, and crowd activities. This regulation is listed and based on Instruksi Menteri Dalam Negeri (Inmendagri) Nomor 35 Tahun 2021 which classified to be 4 level of mass restriction. This regulation restrict academic related activities, non-essential sectors, and essential sectors with the higher the regulations applied, the stricter restriction will applied. Also, there is no duration for how long this regulation will last since the regulation are applied with levels mentioned before based on following conditions. If the Covid-19 pandemic getting worse or increase in reported case related to Covid-19 increase, the regulation implementation will be extended.

This paper is based on assumptions or hypothesis which states that one of the reasons of Covid-19 spread and its following effect are caused by ill-prepared government. This paper also mention about following effect of the issue mentioned before such as society problems. To support the hypothesis, this paper is written by taking several references related to base assumptions. One of the references is a study entitled "Implementasi Pembatasan Sosial Berskala Besar, Sebuah Kebijakan Publik Dalam Penanganan Pandemi Covid-19" in the Jurnal Ilmu Administrasi Negara, Volume 16, Number 1 written by Ahmad Fauzi. This study focus on PPKM (Pemberlakuan Pembatasan Kegiatan Masyarakat) policy [1].

In addition to support the study, the author also takes references related to the study from a study entitled "Analisis Pengangguran dan Pertumbuhan Ekonomi sebagai Akibat dari Pandemi Covid-19" in the Jurnal Ekonomi \& Manajemen Universitas Bina Sarana Informatika written by Siti Indayani and Budi Hartono. This study mainly discuss about the declining of Indonesia economy conditions as a following effect of the Covid-19 Pandemic. It is stated that the Indonesia economic growth are declining by $2,41 \%$ as the result of Covid-19 Pandemic on 2020. This condition are caused by declining productivity from formal and informal field of work and rising unemployment rate [2]. The next reference is entitled "Problematika Kebijakan Pendidikan di Tengah Pandemi dan Dampaknya Terhadap Proses Pembelajaran di Indonesia" written by Ahmad Muwazir Saleh. This study focus on the effect of PPKM policy on academic activities [3].

The other effect following the Covid-19 Pandemic is increase rate of cyber threat which was studied by Gatot Edi Pramono and written in the paper entitled "Telaah Kritis Kejahatan 
Penyebaran Hoaks Saat Pandemi Covid-19" in the Jurnal Ilmu Hukum Fakultas Hukum Universitas Riau Vol.9 Number 2, which focused on hoaxes and fake news issue related to Covid-19 Pandemic [4].

\section{Methodology}

This paper discusses and studies the effect that caused rapid spread of the Covid-19 Pandemic with analysis of public perceptions on regulations and actions made by Government of the Republic of Indonesia. The study conducted is based on research with qualitative method. The data used in this study will be gathered with two stage of data gathering methods combined. First method of data gathering is using secondary data. Secondary data is certain data which selected, gathered and accumulated from other studies and examinations with certain correlations and similiarity object of study prior to this study. Second method of data gathering is by observations and interviewing key actors to accumulate opinions, where opinions gathered are related to the main hypothesis of this paper. After the data are deemed sufficient, then it will be analyzed using relevant theory.

\section{Study Objective}

This study is aimed to achive certain objective, such as:

a. Explain the correlations between Government of the Republic of Indonesia's regulations, pandemic effect, and people's conditions post-pandemic.

b. Explain how effective regulations against Covid-19 pandemic and its following threats such as cyber threats, economical condition decline, disbelief, confusion, and other social problems.

c. To answer the hypothesis which stated that ill-prepared government for dealing with pandemic leads to worsen its effect on people.

\section{Result and Discussion}

The result of this paper are taken from facts and data gathered which are combined, examined, and analyzed. Facts and data are taken from two sources which are other studies with related object of study prior of this study and real life facts which taken from interviews and observation. The keywords "government", "policy", and "people's condition" are selected to base this study in order to answer the hypothesis stating that ill-prepared government for dealing with pandemic leads to worsen its effect, especially on people's live condition. After these combined facts and data are analyzed, the author will discuss with descriptive method and based on related theories. Based on that statements, author will only focus on studying facts and data related to: government policy or regulations related to pandemic, effect of government's regulations both for the pandemic and the people, and people's perpective about pandemic and its regulations.

\subsection{Government's Regulations for Dealing with Covid-19}


After Covid-19 Pandemic occured, it affected people's life and how they live. To reduce the pandemic effect on people and its spread rate, Government of Republic of Indonesia issues PPKM (Pemberlakuan Pembatasan Kegiatan Masyarakat) policy which restrict and regulate people's activity. Activities regulated in this policy are all activities involving gathering of individuals, physical contacts, indoor activities, and outdoor activities. This mass social restriction aim to reduce Covid-19 virus spread rate by limiting any direct contact made by people. For example, activities that are regulated by PPKM policy are office works, field works, academic activities, and commerce related activities. There are four level of PPKM policy which will be applied based on current conditions. The higher the level, the stricter the restriction applied.

The result shown on August 1, 2021 where PPKM proved that it decreased the Covid-19 related case for $2.2 \%$ daily with increasing trend for up to overall $48 \%$. This result leads to decreasing Bed Occupation Rate (BOR) by up to $70 \%$. It also decreases red zones in Jawa Barat and DKI Jakarta, which before PPKM, all cities are red zones. After PPKM policy applied, there are only 12 cities with high risk of Covid-19. In Central Java, PPKM policy are yet to achieve its target. Its target are 50\% decrease in people's activity, but proven far from target. Implementation of PPKM policy in Semarang according to Central Java Governor Ganjar Pranowo are not consistent. The reason of this is people think that the policy are no longer applied, and there is no instructions from city government apparatus. Despite of this, the rate of Covid-19 related case were decreased.

According to journal entitled "Implementasi Pembatasan Sosial Berskala Besar, Sebuah Kebijakan Publik Dalam Penanganan Pandemi Covid-19" by Ahmad Fauzi, PPKM policy may not be the best option for dealing with Covid-19 Pandemic. The journal mainly stated two things about the PPKM regulation or Mass Social Activity Restriction. The first statement is the understanding about legal basis that used as base for implementation of the regulation is rather ambiguous and confusing. There are biases regarding perceptions and understanding of the regulation. The reasons of this condition is (1) this regulation is classified as emergency regulation which its implementation is rather sudden. (2) Lack of understanding between government that caused biases occured on regulation's implementation. (3) Some of city major still unable to understand the regulation completly. (4) There is no clarity about penalty, subsidy, duration, and action of the regulation. (5) Lack of lockdown mechanism and its implementation is rather vague. The second statement is this regulation is only implemented and applied perfectly in Java and Bali regions, especially in Jakarta and city surrounding it such as Bogor, Depok, Tangerang, South Tangerang, and Bekasi.

Further examinations of PPKM policy are conducted in journal entitled "Problematika Kebijakan Pendidikan di Tengah Pandemi dan Dampaknya Terhadap Proses Pembelajaran di Indonesia" by Ahmad Muwazir Saleh. This study stated that academic activities restriction, which force all academic related activities are conducted online with the aim to decrease physical contact and reduce the spreading of Covid-19 virus by avoiding crowd to be formed. As the effect of this, both student and lecturer have to conduct academic activities via online conference, and do their assignment online. The problem stated in this study is that internet network facilities are yet to spread evenly across the country. There are students from isolated places unreached by internet facilities provider makes them harder to do academic activities, often the study materials are unable to reach these students.

Facts and data gathered by this study shown similar result to journals mentioned before. Also, in the policy, there is no duration mentioned which indicated that this regulations will applied for no certain duration. On its application, there is also no certain action can be seen or feel beside closing of most of places that potentially creating crowd such as malls, schools, 
universities, and tourist attraction places. PPKM policy is also an emergency policy which its implementations are sudden. This indicated that there is a lot of people are not ready, understand, even knowing about the regulations. This is contradictory from John Rawls' Theory of Social Justice. According to Rawls, which its theory adopted from Jean-Jacques Rousseau theory, stated that human are naturally free and independent. They have certain set of individual freedom. They also need other individuals to fulfill their needs such as peace, life, protection, and social needs. For this to happens, humans need understanding each other in form of social contract in order to maintain commitment. In other words, human need to understand and agree each other. In other words, every contract, or in this case policy, need to be understood and agreed by both side.

Author mentioned most of places, because this regulations also contradictory. Malls are start to open again with certain regulations whereas most of school are still closed and all academic activities are still conducted online. In order to minimize this contradictory effect, government encourage students and lecturers to continue conducting academic activities online by giving them mobile data. Each cities have different subsidy, but the range of mobile data given is around 5 gigabite to 10 gigabite for certain periods, usually for a month. This also has problems. For example, there is still certain places that unable to reached by internet provider, not every student have phone, and mobile data subsidy are based only on certain providers.

Another effect caused by pandemic is decreasing economy rate and increased unemployment. According to journal entitled "Analisis Pengangguran dan Pertumbuhan Ekonomi sebagai Akibat dari Pandemi Covid-19" written by Siti Indayani and Budi Hartono. It is stated that the Indonesia economic growth are declining by $2,41 \%$ as the result of Covid19 Pandemic on 2020. This condition are caused by declining productivity from formal and informal field of work and rising unemployment rate. Contradictory of this condition, in 20002007 shown that economy rate conditions were increasing by $0,56 \%$ per year. From this study, it can be confirmed that there is correlations between productivity and unemployment rate, and both are affected by mass social restriction policy. PPKM policy decreases worker capacity for up to $50 \%$. Less worker or producer means less production which leads to less selling and it means less profit. In order to minimize expenditure, producer need to dismiss part of its employees, thus leading in increased of unemployment rate.

\subsection{People's Perspective about Pandemic Related Policy}

Biases and uncertainty of PPKM policy has caused confusion both people, government apparatus, and city government. Eventhough PPKM policy has proven successful decreasing Covid-19 related case, uncertainty and biases in the policy caused confusion both government apparatus and the people. Economic condition rate declined, unemployment rate increase, and other social issues caused as the effect of mass social restriction eventually leads to more social problem such as weariness, refusal, and some even become disbelief in both the government and the pandemic itself.

The condition of people's disbelief potentially get worse because of cyber threats such as fake news, phising, conspirations, and misinformations or hoaxes. According to journal entitled "Telaah Kritis Kejahatan Penyebaran Hoaks Saat Pandemi Covid-19" by Gatot Edi Pramono, the freedom and convenience of social media caused provocative, conspiracies, fake, and misleading news easier to be spreaded and circle around society which potentially harmful. This conditions get worse after Covid-19 pandemic occurs. Misleading news about Covid-19 has the potential to risk people's life severely. This cyber threat can lead to disbelief 
in Covid-19 pandemic itself, thus can worsen the effect. This study stated that lack preparation of the pandemic are the main reason hoaxes appears and spreaded rapidly. This paper also mentioned that lack of government action regarding hoaxes and fake news worsen the effect of uncertainty, disbelief, and confusion around people.

\section{Conclusion}

Based on the results of analyzed combined facts and data gathered from other related studies and real life condition, the topic of ill-prepared government for dealing with pandemic worsen its effect on people, can not be said as true, but can not be inferred as fake either. PPKM policy, which is Government of Republic of Indonesia's policy, is proven successful in order to decrease Covid-19 related case rate by quite significant percentage. Eventhough it proven successful at supressing Covid-19 spread, this regulation has serious effect on the people. PPKM policy restrict people's activity which leads to decreasing productivity rate, decreasing economic condition rate, increasing unemployment rate, and created a lot of social problems such as weariness, refusal, and even disbelief. PPKM also heavily focused on Java and Bali, especially West Java and DKI Jakarta. It also contain biases on its policies which has caused uncertainty and confusion among people and part of government itself. According to this, it can be concluded that government preparations in order to deal for very serious problems, including Covid-19 Pandemic, is crucial. It is proven that emergency policies are not the best solution because it is sudden, forceful, very burdening, and might oppress the people. With well-preparations, government can produce regulations with better result and less side effect. From that statements, it also can be concluded that PPKM policy may not be the best regulations to deal with Covid-19. This can serve as an evaluations for the government to see the public's response in the policy taken so that each policy can be evaluated for the better.

\section{References}

[1] Sholeh, Khudori A. Mencermati Teori Keadilan Sosial John Rawls. Jurnal Ulul Albab, Vol. 5 No. 1, 2004.

[2] Indayani, Siti and Budi Hartono. (2020). Analisis Pengangguran dan Pertumbuhan Ekonomi sebagai Akibat Pandemi Covid-19. Perspektif: Jurnal Ekonomi \& Manajemen Universitas Bina Sarana Informatika. Vol.18 Number 2.

[3] Fauzi, Ahmad. (2020). Implementasi Pembatasan Sosial Berskala Besar, Sebuah Kebijakan Publik Dalam Penanganan Pandemi Covid-19. Jurnal Ilmu Administrasi Negara. Vol. 16 Number 1.

[5] Saleh, Ahmad Muwazir. (2020). Problematika Kebijakan Pendidikan di Tengah Pandemi dan Dampaknya Terhadap Proses Pembelajaran di Indonesia. Universitas Islam Negeri Alaudin Makasar.

[6] Pramono, Gatot Edy. (2020). Telaah Kritis Kejahatan Penyebaran Hoaks Saat Pandemi Covid-19. Jurnal Ilmu Hukum Fakultas Hukum Universitas Riau. Vol. 9 Number 2

[7] Nuraini, Tantiya Nimas. "Kronologi Munculnya Covid-19 di Indonesia hingga Terbit Keppres Darurat Kesehatan". https://www.merdeka.com/trending/kronologimunculnya-covid-19-di-indonesia-hingga-terbit-keppres-darurat-kesehatan-

kln.html?page=1 (accessed on August 25, 2021). 
[8] Nugraheny, Dian Erika. "UPDATE 30 Januari: Tambah 14.518 Kasus Covid-19 di Indonesia, Penambahan Tertinggi Selama Pandemi”. https://nasional.kompas.com/read/2021/01/30/16440121/update-30-januari-tambah14518-kasus-covid-19-di-indonesia-penambahan (accessed on August 25, 2021).

[9] Nuryanti. "BREAKING NEWS Update Corona Indonesia 27 Agustus 2021: Tambah 12.618 Kasus, Total $\quad 4.056 .354 \quad$ Positif”. https://www.tribunnews.com/corona/2021/08/27/breaking-news-update-coronaindonesia-27-agustus-2021-tambah-12618-kasus-total-4056354-positif (accessed on August 25, 2021).

[10] Gabrilin Abba. "7 Fakta Keberhasilan PPKM di Jabar dalam Sepekan Terakhir". https://regional.kompas.com/read/2021/08/08/070000478/7-fakta-keberhasilan-ppkmdi-jabar-dalam-sepekan-terakhir?page=all (accessed on August 28, 2021).

[11] Anwar, Rosikhan. "Evaluasi PPKM Level 4 Jawa Tengah Tunjukkan Hasil Membaik". https:/www.suaramerdeka.com/jawa-tengah/pr-04575795/evaluasi-ppkm-level-4jawa-tengah-tunjukkan-hasil-membaik?page=all (accessed on August 28, 2021) 